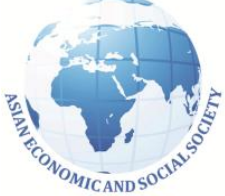

AESS

\section{Asian Journal of Empirical Research}

http://aessweb.com/journal-detail.php?id=5004 DOI: $10.18488 /$ journal.1007/2016.6.4/1007.4.101.116

\title{
IMPACT OF DOMESTIC PUBLIC DEBT ON ECONOMIC GROWTH - AN EMPIRICAL STUDY IN THE INDIAN CONTEXT
}

\author{
Srinivasa Rao Gangadharan \\ Institute for Financial Management and Research (IFMR), Chennai, Tamilnadu, India
}

\section{Lakshmi Padmakumari}

Ph.D Scholar; Institute for Financial Management and Research (IFMR), Chennai, Tamilnadu, India

\section{Article History:}

Received: 3-May-2016

Revised received: 7-June-2016

Accepted: 27-June-2016

Online available: 25 -July-2016

\section{Keywords:}

Domestic debt, economic growth, deficit, crowding out, ARDL, granger causality

\begin{abstract}
This study is an empirical investigation to assess the impact of domestic debt on India's Economic growth during the period 1980 - 2014. We use data on Domestic Debt, Net Fiscal Deficit, Exports, Savings, Real Gross Domestic Product, Population and Terms of Trade. This study adopts the ARDL Co-Integration and Granger Causality techniques to investigate the relation between the key variables. The study also employs various post estimation tests to validate the fitness and stability of the models based on Gauss Markov assumptions, after employing the ordinary least square regression on various models. We find that debt negatively impacts economic growth while savings has a positive impact. The Auto Regressive Distributed Lag (ARDL) technique used to test the robustness suggests existence of co-integration among the variables. However, none of the long run co-efficient is significant. The granger causality and co-integration test results support the traditional view that debt negatively impacts economic growth.
\end{abstract}

\section{INTRODUCTION}

Governments resort to public borrowings (domestic and external) to bridge the resource gap between their revenues and expenditures. Many prefer domestic borrowings, as the burden of repayment of domestic debt would be less than that of external debt. However, if their domestic markets are not well developed, they go in for external borrowings.

This resource gap in India has been widening year after year. From USD 0.22 million in 1990-91, the gap has widened to USD 3.41 million in 2014-15. In the last 25 years, the gap has multiplied by 15 times. No improvement in the growth of both revenues and expenditures is the contributing factor for the wide resource gap during this period.

Corresponding author's

Name: Srinivasa Rao Gangadharan

Email address: ganga@ifmr.ac.in 
In fact their growth rate has come down from 15 percent during the decade $1991-2001$ to 14 percent during the decade 2001-2010 and the same growth continued in the last 5 years (2010 2015).

The main sources of domestic borrowings for the Government of India are through raising public loans, use of fiscal instruments such as Treasury Bills, borrowings from financial institutions and obtaining credit through the Reserve Bank of India. Besides this, the funds generated throughNational Savings Schemes (NSS) provide a substantial amount of resources to the government.

The Public Sector Enterprises (PSEs) are also permitted to borrow funds from the public through bonds, public deposits, and other financial instruments.

In India, the domestic capital receipts are the major source of funds to bridge the resource gap. The share of the domestic capital to bridge the resource gap increased from 72 percent of the total capital receipts in 1990-91 to 98 percent in 2014-15. Domestic debt (USD 1.09 million) that constituted 90 percent of the total debt (USD 1.21 million) in 1990-91, has increased to 97 percent (USD 23.21 million) in 2014-15. As a result, the debt burden on each Indian has multiplied by 14 times since 1990-91. From USD 123.54 in 1990-91, it has increased to USD 736.65 in 2014-15. The per capita debt is growing at a faster rate than per capita income. According to the Ministry of Finance, per capita income increased at the rate of 14 percent per annum, the per capita debt increased at 23 per cent annum during 2012-13 to 2014-15.

Three items that do not have any debt tag attached in the domestic capital receipts are (a) Repayment of Loans and Advances lend by the government (b) Receipts from disinvestment of government equity capital and (c) Miscellaneous receipts. Continuous incremental flow of these three receipts will reduce the debt burden and pave the way for the developmental growth of the country. Unfortunately, the flow has been discontinuous and widely fluctuating. The share of these three items as a percentage of the total domestic capital receipts has come down from 20 percent in 1990-91 to 14 percent in 2014-15. In between two times in recent years 2009-10 \& 2011-12, its share has been just 3 percent of the domestic capital receipts.

Recovery of loans and advances by the public sector banks will come in a big way for the developmental growth of the country as the recovered money will be recycled for others in need of fund. Unfortunately, nearly USD 1.54 million of the Public Sector Banks advances are outstanding as Non-Performing Assets (NPAs). The NPAs as a percentage of total assets of the PSU Banks has increased from 5.43 percent (USD 1.03 million) in 2014-15 to 7.30 percent (USD 1.39 million) for the year $2015-16$. The increase in the percentage of NPAs year after year has pushed the banking sector into a big distress. Interestingly, the NPA of PSU Banks (USD 1.54 million) for the year 2015 -16 is more than their market capitalization (USD 1.01 million). So recovery of NPAs is of prime concern to the government in reducing the domestic debt burden of the country.

\section{Table1: Key debt Indicators of India}

\begin{tabular}{llcc}
\hline SI.No. & \multicolumn{1}{c}{ Debt Indicators } & 1990-91 & 2014-15 \\
\hline 1 & Resource Gap (Expenditure - Revenue) (USD million) & 0.22 & 3.41 \\
2 & Domestic Capital Receipt as a \% to total Capital Receipt & $72 \%$ & $98 \%$ \\
3 & Domestic Debt as a percentage to Total Debt & $90 \%$ & $97 \%$ \\
4 & Per-capita Domestic Debt (USD) & 123.54 & 736.65 \\
5 & Market Loans as a \% of Resource Gap & $18 \%$ & $77 \%$ \\
6 & Debt component as a \% of Domestic capital receipts & $26 \%$ & $80 \%$ \\
7 & Domestic Capital receipts that do not have a debt tag as a & $20 \%$ & $14 \%$ \\
8 & percentage of total capital receipts & $33 \%$ & $6 \%$ \\
9 & Future generation fund as a \% of domestic capital receipts & 0.096 & 2.37 \\
\hline
\end{tabular}

Source: Handbook of statistics, Indian economy, RBI 
Note:Amounts in Indian Rupees converted into US dollar using the Purchasing power parity conversion factor Another important source of domestic capital receipts that comes in a big way in reducing the debt burden is the small savings and the provident fund. This fund belonging to the future generations is used by the government for reducing the debt burden and also for making interest payments. This source accounting 33 percent of the domestic capital receipts in 1990-91, has come down drastically to 5 percent from $2010-11$ onwards till today.

The component that form major part of the domestic capital receipts is the Market Loans. They accounted for 18 percent of the domestic capital receipts in 1990-91. Their share increased to 77 percent in 2014-15. Market loans stimulate the debt burden of a country. In the last 25 years, the market loans multiplied by 65 times. From USD 0.040 million in 1990-91, it has increased to nearly USD 2.69 million in 2014-15. In India, the interest payments for the loans borrowed have multiplied by 25 times. From USD 0.096 million in 1990-91, it has increased to USD 2.36 million.

Coming to the legal aspects on the debt control mechanism in India, presently, there is no direct legal control with regard to public borrowing incurred by the Government. There is also no control over the expenditure on debt charges (including interest) that are charged on consolidated fund without being subjected to the approval of the Parliament. However, Article 292 of the Constitution of India empowers the Union and State Governments to borrow upon the security of the Consolidated Fund of India under certain conditions and within certain limits fixed by law of the Parliament from time to time ${ }^{1}$. There are various options available for fixing limits to the public debt (yearly ceiling in absolute terms or as a proportion of GDP or of total government expenditures, or ceiling for a five-year period broadly in relation to public investment). The Government has so far not acted on these provisions.

The Comptroller and Auditor General of India (CAG) made a detailed analysis on the debt management process of the Union Government in 1987. The report covered analyses of deficits and debts, the increasing trends in government borrowing and its consequences. The report indicated the need for improvement in financial management and mentioned that the government has made no reference about ceiling on public debt anywhere. The Public Accounts Committee of Parliament (PAC) expressed dissatisfaction over the prevailing arrangement of publication of the borrowing programme in the five-year plans and the annual budgets and having discussions thereon in the Parliament.

India's worry is growing domestic debt burden and increasing debt servicing cost that absorbs major part of government revenues. Country is left with little money to spend for the developmental purpose. Domestic debt needs to be deployed judiciously till the projects payback. A shrewd domestic public debt management stimulates economic growth and stability through mobilizing resources with low cost borrowing and limiting financial risk exposure. At the same time, incautious borrowing (terms, interest rate and the overall costs of financing the debt) may impact the economy, future of the enterprises and social welfare for the present as well as the future generations of the country.

\subsection{Motivation for undertaking the study}

We are primarily motivated by a research paper titled "Domestic debt and Economic Growth in India" by Charan (1999) where he investigated the relationship between domestic debt and economic growth in India using the co-integration and Granger causality tests for the period 195995. Though we have attempted similar approach, we are unique on two counts. First our study period covers 1980-2014 during which a lot of structural changes have taken place; especially the role of private sector has undergone sea changes in the economic growth of the country. Their share in the total corporate profits, share in the total investment and addition of power generating capacity has increased by more than 50 percent. New areas (Airports, Ports and Highways) opened for private sector. Besides this, big push to the Indian economy in the form of economic reform

\footnotetext{
${ }^{1}$ Entries 35 and 37 of List I of the Seventh Schedule
} 
programme took place in 1991. Second, Charan Singh's study supports Ricardian equivalence hypothesis, our study supports the traditional view (debt negatively impact economic growth in the long run).

The rationale for examining the impact of domestic debt, rather than external debt on India's economic growth is that in the last five years $(2010$ - 2015), India's external borrowing account for less than 1 percent $(0.92 \%)$ of the total capital receipts. This is one of the reasons we are not affected by the Asian Crisis and not much by the Global Financial Crisis. So we presume that external borrowing may not have much impact on India's economic growth. Another supporting evidence of dependence on domestic debt for India's Economic growth is that India has a well-developed domestic capital market.

So a study on the impact of domestic debt on the Economic growth during the period in which India has undergone some structural changes would be of immense help to the academicians and the policy makers in designing their future course of actions in bringing down the debt burden.

The paper has been organized into four sections: Section 2 reviews the literature; Section 3 describes the data and methodology used in the paper. Section 4 explains the empirical findings and section 5 concludes the paper with recommendations for policy implications.

\section{REVIEW OF LITERATURE}

The Review of literature of this paper is focused on theoretical relationship between domestic public debt and economic growth, studies on domestic debt and economic growth across countries in the world and in India.

The theoretical relationship between domestic borrowing and economic growth is explored both from the Traditional and the Ricardian point of view. The traditional view says an increase in government debt is a burden on the economy. It explains the relationship both from the short and long run perspectives. In the short run, consumer resort to higher spending because he feels that he is affordable to increase his consumption with the increased inflow of government borrowing. This increases the demand for goods and services which in turn increases the output and employment in view of the sticky short run prices. As the marginal propensity to consume is higher than the marginal propensity to save, the increase in private savings falls short of the government dissaving ${ }^{2}$. The real interest rate would rise in the economy that would encourage external borrowings.

The higher interest rate in the long run, keeps away private investment which in turn leads to a lower steady state capital stock. As a result, the overall impact in the long run would be smaller total output, lower consumption and reduced economic welfare. This is also referred to as the burden of public debt, as each generation burdens the next, by leaving behind a smaller aggregate stock of capital (Meltzer 1951; Modigliani 1961; Ferguson 1964; Patinkin 1965).

Many economists have studied the issue of domestic debt as a burden on the future generation; notable among them are Buchanan (1958) and Barro (1978). While Buchanan study implies that domestic debt shifts current tax liability to future generations, Barro study argues that such shifts in tax liability do not burden future generation due to inter - generational transfers. It was assumed that infinite lives, timing of taxation, public debt and capitalized future taxes as perfect substitutes.

On the other hand, Ricardian view considers that government debt is equivalent to future taxes (Barro, 1974). Thus, in the long run, debt does not impact economic growth as the shift between taxes and deficits does not influence wealth.

\footnotetext{
${ }^{2}$ The use of savings to fund spending that is greater than income
} 
Coming to the review of literature on the theoretical and empirical studies on our topic, we find that most of the studies revolve around external debt and debt restructuring on growth in developing countries. The empirical literature is scarce, despite the fact the topic has been widely debated both in the academic and public policy forums (Cashell, 2007). The outcome of the few studies on the impact of debt and economic growth are dichotomy in their results. Many have come out with the result that increased domestic debt leads to negative growth in the economy. There are also studies that have come out with positive economic growth due to the flow increased domestic debt in the economy.

Those advocating negative impact on economic growth (Smith, 1776;Ricardo, 1951;Mill, 1845;Kemal, 2001;Kristineet al., 2011, Ismihan and Ozkan, 2012;Anjaet al., 2012) are of the view that Government borrowing from the domestic market; crowd out private sector in seeking this fund. As a result they have to borrow at higher market rates. This reduces economy's growth rate and adversely affect the trade balance.

At the same time there are studies (Karazijienè and Saboniené, 2009;Abbas \& Christensen, 2007; and Charan, 1999) that advocate domestic debt will have positive impact on economic growth. They are of the view that domestic debt stimulates the economy by the inflow of safe and low interest rate funds $^{3}$ that generate additional surplus to the economy. This will benefit the economy if they are effectively monitored and controlled.

\subsection{Review of literature on domestic debt and economic growth across the countries}

A study on debt and its implication on growth in Pakistan by Kemal (2001) show that debt buildup and its interest cost adversely affects poor people. The study exemplify that though debt to GDP ratio of Pakistan exceeds that of all countries in South Asia, it is not still so high as to go for debt write off. This infers that Pakistan has the capacity to service its debt.

Jakob (2005), in a study on the role of domestic debt markets involving a cross country survey of 27 sub-Saharan African countries for a 20 year period found that domestic markets have narrow investor base due to their small size and highly short term nature.

A study by Abbas and Christensen (2007) on the impact of domestic debt on economic growth in low income countries (including 40 sub-Saharan Africa countries) and emerging markets between 1975 and 2004 found that a reasonable level of marketable domestic debt as a percentage of GDP have significant positive impact on economic growth. The study provided evidence that debt levels exceeding 35 percent of total bank deposits have negative impact on economic growth.

\subsection{Review of literature on domestic debt and economic growth with respect to India}

There are very few studies on domestic debt and economic growth with respect to India. Many of them are very old. The studies by Rao (1953), Brahmananda (1980) and Minhas (1987) focused on India's domestic debt and economic growth when India was categorized as an "Under Developed" country. But what we see in India today is totally different from what these economists have seen. At that time, India was categorized as underdeveloped country with insufficient equipment and unutilizable resources and high disguised employment. For instance, Minhas (1987) argues that debt and growth are not related in India and the Keynesian pump-priming ${ }^{4}$ track is not applicable to Indian condition. At that time India was not having excess idle capacity in plants and machinery. But today, India has an expanded capacity of machinery and pump-priming is necessary for India to stimulate private spending that lead to economic expansion.

A common view among them was that domestic debt in India is being incurred to meet the current expenditure rather than for investment purpose. Chelliah (1991) argues that domestic borrowing

\footnotetext{
${ }^{3}$ State bonds, treasury bills and loand

${ }^{4}$ an action taken to stimulate an economy, usually during a recessionary period, through government spending, interest rate and tax reductions
} 
from the public has been used for financing, thereby increasing government expenditure other than capital formation. The RBI report (1985) also supports the same view.

To sum up, the review of literature reveals, domestic debt is a burden on the future generation. In the short run, increase in the domestic debt leads to increased demand which in turn increases output and employment. In the long run, high interest rate discourages investment, smaller output and reduced economic welfare. Outcome of the studies on domestic debt and economic growth are dichotomous in their results. Many studies reveal negative impact on economic growth due to increased domestic debt and interest rate. Studies with positive impact on economic growth due to increased domestic debt attribute the outcome due to the inflow of safe and lower interest rate funds. Studies on Domestic debt undertaken in Pakistan, Sub - Sahara African countries shows that domestic markets in these countries are generally small, highly short term and often have a narrower investor base. Studies on India reveal, that domestic debt is incurred to meet current consumption expenditure rather than for investment.

\section{DATA AND METHODOLOGY}

The study uses officially published secondary data by the Government of India in the Union budget (2014-15), Economic Survey (2014 -15) and the data from the Handbook of Statistics on Indian Economy by the Reserve Bank of India (2014-15). The base year selected for the study is 2004-05 and the sample period ranging between 1980 to 2014.The variables are constructed in the following way:

- Debt is domestic liabilities of the centre, as a percentage of GDP.

- Net fiscal deficit of Government of India as a percentage to GDP (NFD).

- Exports are the sum of oil and non-oil commodities at current prices, as a percentage to GDP.

- Savings is Gross domestic savings at current prices, as a percentage to GDP.

- Population growth rate is percentage change in population growth (POPGR).

- TOTGR is growth rate of terms of trade. We include this variable to expand the model beyond a closed economy.

- GDPGR is the growth rate of real GDP at factor cost.

\section{METHODOLOGY}

Since all the variables modelled here are not $I(1)^{5}$, we cannot apply co-integration technique. If we take first difference to make the variables $I(0)$, we lose the long run information embedded in the data. Given the mixture of variables ${ }^{6}$, we think it is best to use the "General to Specific Modelling procedure (GETS)" estimation technique suggested by Hendry (1996). This estimation technique involves using both lagged dependent and independent variables to uncover a parsimonious ${ }^{7}$ model. In this we estimate the equation with first differenced lagged variables (to embed long run information and also achieve stationarity). We then simplify the model by dropping statistically insignificant coefficients to zero. The final model is put into various diagnostic tests to ensure that the assumptions of classical linear regression model are compiled. We take up to maximum two lags as we are dealing with annual data.

\footnotetext{
${ }^{5} I(1)=$ non stationary and $I(0)$ is Stationary.

${ }^{6}$ We also estimate Auto regressive Distributed Model (ARDL). The results are discussed later in this paper.

${ }^{7} \mathrm{~A}$ model that accomplishes a desired level of explanation or prediction with as few predictor variables as possible.
} 
Table 2: Summary statistics of the key variable

\begin{tabular}{lcccccccc}
\hline Variable & Obs & Mean & Std Dev & Min & Max & Skewness & Kurtosis & JB Statistic* \\
\hline Debt & 34 & 47.65 & 7.28 & 31.77 & 59.64 & -0.35 & 2.88 & 0.70 \\
NFD & 34 & 4.36 & 0.93 & 2.42 & 6.35 & -0.08 & 2.47 & 0.81 \\
Exports & 34 & 9.58 & 4.29 & 4.15 & 17.47 & 0.46 & 1.99 & 0.27 \\
POPGR & 34 & 1.84 & 0.33 & 1.25 & 2.31 & -0.34 & 1.68 & 0.21 \\
Savings & 34 & 24.98 & 5.98 & 17.10 & 36.8 & 0.42 & 1.86 & 0.24 \\
TOTGR & 34 & 0.59 & 10.82 & -31.26 & 23.97 & -0.25 & 4.00 & 0.42 \\
GDPGR & 34 & 6.21 & 2.14 & 1.43 & 10.16 & -0.03 & 2.28 & 0.69 \\
\hline
\end{tabular}

Note: * P-values of the JarqueBera test are provided

From Table 2, we infer that all the variables except exports and savings are negatively skewed. We have a total of 34 observations. From the JB test p-value, we find that none of the variables are significant at 95 percent confidence level and hence we conclude that all the variables follow normal distribution.

\subsection{Unit root results}

We test for stationarity of the time series variables by adopting Augmented Dicky Fuller Test. The null hypothesis of ADF test is that variables are non-stationary. From Table 3, we find that GDPGR, POPGR, NFD and TOTGR are $I(0)$ at level where as exports, savings and debt are $I(1)$ at $5 \%$ level of significance. These variables become stationary on first differencing.

Table 3: ADF unit root test results

\begin{tabular}{lccc}
\hline & \multicolumn{2}{c}{ Level } & First Difference \\
\cline { 2 - 4 } & Trend \& Intercept & Intercept & Intercept \\
\hline GDPGR & - & $-4.32(0.00)^{* *}$ & -- \\
NFD & $-3.55(0.04)^{* *}$ & $-3.41(0.00)^{* *}$ & - \\
Exports & $-2.71(0.24)$ & $0.98(0.99)$ & $-7.40(0.00)^{* *}$ \\
Savings & $-2.09(0.53)$ & $-0.96(0.75)$ & $-6.60(0.00)^{* *}$ \\
POPGR & $-4.58(0.00)^{* *}$ & $0.45(0.98)$ & -- \\
Debt & $-1.86(0.65)$ & $-2.72(0.18)$ & $-3.51(0.01)^{* *}$ \\
TOTGR & $-5.27(0.00)^{* *}$ & $-5.66(0.00)^{* *}$ & -- \\
\hline
\end{tabular}

Note:All the variables appear to have deterministic trend. In the Augmented Dicky fuller (ADF) test on the level of variables, we include both trend and constant, but no trend is included in the tests on first-differenced variables.

P-values are given in parenthesis.

- implies since the it does not have a trend, we only performed "intercept" version of the ADF test

-- denotes test at first difference is not conducted since we found the variable is stationary at level

$* *$ denotes significance at $5 \%$

The correlation matrix for the stationary variables is presented in Table 4 .

Table 4: Correlation matrix

\begin{tabular}{|c|c|c|c|c|c|c|c|}
\hline Correlation & GDPGR & D(DEBT $)$ & D(EXPORTS) & D(SAVINGS) & NFD & POPGR & TOTGR \\
\hline GDPGR & 1.00 & & & & & & \\
\hline & ----- & & & & & & \\
\hline D(DEBT) & $\begin{array}{c}-0.63 \\
(0.00)^{* *}\end{array}$ & 1.00 & & & & & \\
\hline D(EXPORTS) & $\begin{array}{c}-0.01 \\
(0.94)\end{array}$ & $\begin{array}{l}-0.12 \\
(0.52)\end{array}$ & $\begin{array}{l}1.00 \\
-----\end{array}$ & & & & \\
\hline D(SAVINGS) & $\begin{array}{c}0.17 \\
(0.35)\end{array}$ & $\begin{array}{c}0.11 \\
(0.56)\end{array}$ & $\begin{array}{l}-0.27 \\
(0.13)\end{array}$ & 1.00 & & & \\
\hline NFD & $\begin{array}{l}-0.13 \\
(0.47)\end{array}$ & $\begin{array}{c}0.28 \\
(0.11)\end{array}$ & $\begin{array}{c}0.04 \\
(0.83)\end{array}$ & $\begin{array}{l}-0.19 \\
(0.28)\end{array}$ & $\begin{array}{l}1.00 \\
-----\end{array}$ & & \\
\hline POPGR & -0.38 & 0.47 & -0.21 & 0.07 & -0.18 & 1.00 & \\
\hline
\end{tabular}




\begin{tabular}{lccccccc}
\hline & $(0.03)^{* *}$ & $(0.01)^{* *}$ & $(0.24)$ & $(0.70)$ & $(0.32)$ & ----- & \\
TOTGR & -0.06 & -0.04 & -0.40 & 0.04 & -0.22 & 0.26 & 1.00 \\
\hline & $(0.76)$ & $(0.84)$ & $(0.02)^{* *}$ & $(0.82)$ & $(0.22)$ & $(0.14)$ & ----- \\
\hline
\end{tabular}

Note: Values in parenthesis denote the p-values

$* *$ represent significance at $5 \%$

Since GDPGR, POPGR, NFD and TOTGR are $I(0)$ at level where as exports, savings and debt are $I(1)$ at $5 \%$ level of significance, we take their first differenced form namely: D(DEBT), $\mathrm{D}$ (EXPORTS) and D(SAVINGS) respectively.

We find that there exist significant and positive correlation between population growth rate and debt. Terms of Trade has a significant and negative relation with exports. With respect to GDP growth rate analysis, both debt and population growth rate has a significant and negative relation as expected. We can also infer that none of the other variables have any significant positive or negative impact on GDP growth rate.

\section{EMPIRICAL ANALYSIS}

The basic model for our study is:

$$
\begin{aligned}
& G D P G R=\beta_{0}+\beta_{1} \mathrm{D}(D E B T)+\beta_{2} N F D+\beta_{3} \mathrm{D}(\text { EXPORTS })+\beta_{4} \mathrm{D}(\text { SAVINGS })+\beta_{5} P O P G R+ \\
& \beta_{6} T O T G R+\varepsilon \\
& \ldots \ldots \ldots \ldots \ldots \ldots \ldots \ldots \ldots \ldots \ldots \ldots \ldots \ldots \ldots \ldots \ldots \ldots
\end{aligned}
$$

The expected signs are $\beta_{1}$ and $\beta_{5}<0$ (the coefficients of debt and population growth to be negative) and $\beta_{4}>0$ (the coefficient of savings to be positive). We expect as debt increases, GDP growth rate will fall in the long run. They are expected to have a concave relation. Similarly as savings increases, capital accumulation will increase which will in turn lead to increased GDP growth. Rest of the coefficients can be either positive or negative. However, prima facie, as population growth rate increases, GDPGR will fall. Similarly, as net exports increases it will lead to more inflow and GDPGR will increase. A positive net fiscal deficit is expected to lead to better economic growth. We also expect that a favorable Terms of Trade will boost the economy and lead to better economic growth.

The results of the regression are exhibited in Table 5. The independent variables D(DEBT), D(SAVINGS), D(EXPORTS) represent the first differenced variables, whereas NFD, POPGR and TOTGR are level variables. The dependent variable is GDPGR. The second column exhibits the first regression result with the basic model. We wanted to include the lagged dependent and independent variables as per Hendry (1996) approach. We found that only Savings with 1 lag (Savings (-1)) turns out to be significant.

Table 5: Regression results

\begin{tabular}{lccc}
\hline & $\begin{array}{c}\text { Model - I } \\
\text { GDPGR }\end{array}$ & $\begin{array}{c}\text { Model - II } \\
\text { GDPGR }\end{array}$ & $\begin{array}{c}\text { Model - III } \\
\text { GDPGR }\end{array}$ \\
\hline Intercept & -4.70 & -4.92 & $-4.20^{* *}$ \\
D(DEBT) & $-0.56^{* *}$ & $-0.55^{* *}$ & $-0.54^{* *}$ \\
D(EXPORTS) & -0.29 & -0.24 & - \\
NFD & 0.04 & 0.05 & - \\
POPGR & 2.86 & 2.86 & - \\
D(SAVINGS) & $0.36^{*}$ & $0.37^{*}$ & $0.34^{*}$ \\
Savings(-1) & $0.23^{*}$ & $0.24^{*}$ & $0.08^{*}$ \\
TOTGR & -0.01 & - & - \\
R $^{2}$ & 0.53 & 0.52 & 0.48 \\
F-Statistic & $3.94^{* *}$ & $4.75^{* *}$ & $9.15^{* *}$ \\
DW Statistic & 1.96 & 1.95 & 1.91 \\
\hline
\end{tabular}

Notes: $* *$ and $*$ denote $5 \%$, and $10 \%$ level of significance respectively 
So we drop all other insignificant lag terms and run the basic regression model. From the first regression results (Model $-\mathrm{I}$ ), we find that debt is significant and negatively related to GDP growth rate. As domestic debt increases, the growth rate falls. Further, savings is significant and positively related to GDP growth rate. As savings increases, economic growth will also increase. None of the other variables have any significant impact on GDPGR.

Model - II shows regression result after we dropped the insignificant TOTGR variable. We find results similar to Model - I (Debt negatively impacting GDPGR and savings positive impact).

By dropping other insignificant variables (Exports, NFD \& POPGR) we end up with Model III with just three variables: GDPGR, D(DEBT) and D(SAVINGS). From the results, we can deduce a negative relation between debt and economic growth and a positive relation between savings and economic growth.

The goodness of fit of the model is satisfactory as explained by the $R^{2}$ of time series data. Our model explains about 52 percent of total variation in GDP growth rate. F-statistic shows the overall significance of the model. All the F -statistic is found to be highly significant. We reject the null hypothesis and conclude that our model is highly significant. We can also infer that there's no serial correlation and model is significant as the Durbin Watson Statistic (DW) of all the three models are approximately 2 .

\subsection{Post-estimation tests}

We proceed further by conducting the post estimation tests (Omitted Variable Bias, Multicollinearity, Heteroscedasticity, Auto Correlation) for all the three models to see that the Gauss Markov assumptions are adhered. Though the results of these tests are significant for all the three models, we are presenting the test results pertaining to Model - III in Table - 6 . 
Asian Journal of Empirical Research, 6(4)2016: 101-116

Table 6: Results of the post estimation tests with respect to model - III

\begin{tabular}{|c|c|c|c|c|c|c|}
\hline Sl. No. & Test & Statistic & $\mathrm{H}_{0}$ & $\mathrm{H}_{1}$ & Norm & Result \\
\hline 1 & $\begin{array}{l}\text { Omitted Variable } \\
\text { Bias }\end{array}$ & F-Statistic & No omitted variable bias & $\begin{array}{l}\text { Presence of omitted } \\
\text { variable bias }\end{array}$ & $\begin{array}{c}\mathrm{P} \text { - Value }(\alpha)<0.05, \\
\text { reject } \mathrm{H}_{0}\end{array}$ & $\begin{array}{c}\mathrm{P} \text { - Value }(\alpha)=0.66>0.05, \text { we do } \\
\text { not reject } \mathrm{H}_{0}\end{array}$ \\
\hline 2 & Multicollinearity & $\begin{array}{l}\text { Variance inflation } \\
\text { Factor (VIF) }\end{array}$ & & & $\begin{array}{l}\text { VIF }<10 \text {, absence of } \\
\text { Multicollinearity }\end{array}$ & $\begin{array}{c}\text { VIF - D(DEBT })-1.37, \\
\text { D(SAVINGS })-1.03 \text {, Savings }(-1) \\
1.40\end{array}$ \\
\hline 3 & Heteroscedasticity & $\begin{array}{l}\text { Chi-square test } \\
\text { statistics }\end{array}$ & no heteroscedasticity & $\begin{array}{c}\text { Presence of } \\
\text { heteroscedasticity }\end{array}$ & $\begin{array}{c}\mathrm{P} \text { - Value }(\alpha)<0.05, \\
\text { reject } \mathrm{H}_{0}\end{array}$ & $\begin{array}{c}\text { P-value of the chi-square }=0.2886 \\
>0.05 \text {, we do not reject } \mathrm{H}_{0}\end{array}$ \\
\hline 4 & Autocorrelation & $\begin{array}{l}\text { Chi-square test } \\
\text { statistics }\end{array}$ & no auto correlation & $\begin{array}{l}\text { Presence of auto } \\
\text { correlation }\end{array}$ & $\begin{array}{c}\mathrm{P} \text { - Value }(\alpha)<0.05 \text {, } \\
\text { reject } \mathrm{H}_{0}\end{array}$ & $\begin{array}{c}\text { P-value of the chi-square }=0.9808 \\
>0.05 \text { we do not reject } \mathrm{H}_{0}\end{array}$ \\
\hline
\end{tabular}

We also conducted the Stability Diagnostic Test - CUSUM and CUSUM Square test on all our models and found that the models are stable at 95\% confidence level (Please refer Appendix I for the output) 


\subsection{Robustness check using ARDL model}

One need to establish the existence of co-integration among the key variables namely: GDPGR, $\mathrm{D}$ (DEBT) and D(SAVINGS) (from Model III) before we go for Granger Causality testing. Since we are dealing with a mixture of $I(0)$ and $I(1)$ variables, as a measure of robustness, we used the Auto Regressive Distributed Lag (ARDL) technique to study the co-integration among the key variables.We used the ARDL bounds testing approach (Pesaranet al., 2001) for testing whether the ARDL model contains a level (or long-run) relationship between the independent variable and the GDP growth rate. The null hypothesis of ARDL Bounds Test is that there exists no long run relationship. The results are presented in Table 7.

We can conclude from the bounds test F-Statistic that there exists existence of co integration among the variables. So we reject the null hypothesis and establish long run relation. The last panel presents the results for the error correction model estimated. A significant and negative error correction term confirms causality in at least one direction (Granger, 1986). Any deviation in the long run coefficients will be immediately adjusted. We also find that, both the short run coefficients are significant at 95 percent confidence level. Debt is negatively impacting growth rate while savings has a positive impact as expected in the short run. But we find that none of the long run coefficients are significant.

\section{Table 7: The results of ARDL bounds test and co-integration long run form test}

\begin{tabular}{lcc}
\hline & Critical Value Bounds & $I(1)$ \\
Significance & $I(0)$ & 5.06 \\
$10 \%$ & 4.19 & 5.85 \\
$5 \%$ & 4.87 & 6.59 \\
$2.5 \%$ & 5.79 & 7.52 \\
$1 \%$ & 6.34 & \\
& Long Run Coefficients \\
Regressors & Coefficients \\
D(DEBT) & 0.05 & \\
D(SAVINGS) & 0.24 & \\
C & -0.20 & \\
@TREND & -0.12 & \\
Regressors & Co-integrating Form & \\
D(DEBT) & Coefficients \\
D(SAVINGS) & $-0.44^{* *}$ & \\
@TREND & 0.26 & \\
Error Correction & -0.12 & \\
\hline N & $-1.06^{* *}$ &
\end{tabular}

Note:\# K denote number of regressors

Selected Model: ARDL $(1,1,0)$

F-Statistic13.81 $\quad \mathrm{K}^{\#}=2, * *$ denotes $5 \%$ level of significance

\subsection{Checking for granger causality}

In this section, we are interested in analysing the relationship between domestic debt, economic growth and savings. Economic growth is measured by GDPGR. As per Granger (1969), if two variables are co-integrated, in the long run they will converge to an equilibrium relation, even if they don't in the short run. From the ARDL test results, we have already established long run relationship among the variables. The basic intuition behind this test is that if we say that Debt will Granger Cause Economic Growth (GDPGR), it means predictions of GDPGR based on past values of GDPGR and Debt provide a more clear picture than predictions of GDPGR based on its past values alone. The same can be said for savings and GDPGR as well as savings and debt. We use Granger Causality test to study this relation between debt and economic growth, savings and economic growth as well as savings and debt. 


\subsection{Granger causality equations}

Since we need the requirement that both the variables under study be $I(0)$, we are first using the level data of GDP, Debt and Gross Domestic Savings (GDS) (all three are I(1)) and by first differencing, we make $I(0)$. We assume there is no correlation between the error terms $u_{1 t}$ and $u_{2 t}$.

$$
\begin{gathered}
D(G D P)_{t}=\alpha_{0}+\sum_{i=1}^{n} \gamma_{i} D(G D P)_{t-i}+\sum_{j=1}^{n} \pi_{J} D(D E B T)_{t-j}+u_{1 t} \\
D(D E B T)_{t}=\alpha_{1}+\sum_{i=1}^{n} \tau_{i} D(G D P)_{t-i}+\sum_{j=1}^{n} \lambda_{J} D(D E B T)_{t-j}+u_{2 t} \\
D(G D P)_{t}=\alpha_{0}+\sum_{i=1}^{n} \gamma_{i} D(G D P)_{t-i}+\sum_{j=1}^{n} \pi_{J} D(G D S)_{t-j}+u_{1 t} \\
D(G D S)_{t}=\alpha_{1}+\sum_{i=1}^{n} \tau_{i} D(G D P)_{t-i}+\sum_{j=1}^{n} \lambda_{J} D(G D S)_{t-j}+u_{2 t} \\
D(G D S)_{t}=\alpha_{0}+\sum_{i=1}^{n} \gamma_{i} D(G D S)_{t-i}+\sum_{j=1}^{n} \pi_{J} D(D E B T)_{t-j}+u_{1 t} \\
D(D E B T)_{t}=\alpha_{1}+\sum_{i=1}^{n} \tau_{i} D(G D S)_{t-i}+\sum_{j=1}^{n} \lambda_{J} D(D E B T)_{t-j}+u_{2 t}
\end{gathered}
$$

The null hypothesis for this test is as follows:
a. Equation (2) suggests that $D(G D P)$ does not (Granger) cause $D(D E B T)$.
b. Equation (3) suggests that $D(D E B T)$ does not (Granger) cause $D(G D P)$.
c. Equation (4) suggests that $D(G D P)$ does not (Granger) cause $D(G D S)$.
d. Equation (5) suggests that $D(G D S)$ does not (Granger) cause $D(G D P)$.

\begin{tabular}{|c|c|c|}
\hline Lags & $H_{0}: D(G D P)$ does not Granger Cause $D(G D S)$. & Conclusion \\
\hline 1 & $19.05(0.00)^{* *}$ & $\mathrm{GC}$ \\
\hline 2 & $9.30(0.00)^{* *}$ & GC \\
\hline 3 & $4.80(0.01)^{* *}$ & GC \\
\hline 4 & $4.09(0.01)^{* *}$ & GC \\
\hline 5 & $1.80(0.17)$ & Does not GC \\
\hline Lags & $\begin{array}{l}\text { oes not Granger } \\
\text { F-statistic }\end{array}$ & Conclusion \\
\hline 1 & $0.10(0.75)$ & Does not GC \\
\hline 2 & $0.52(0.60)$ & Does not GC \\
\hline 3 & $0.30(0.83)$ & Does not GC \\
\hline 4 & $0.64(0.64)$ & Does not GC \\
\hline 5 & $0.29(0.91)$ & Does not GC \\
\hline
\end{tabular}
e. Equation (6) suggests that $D(G D S)$ does not (Granger) cause $D(D E B T)$.
f. Equation (7) suggests that $D(D E B T)$ does not (Granger) cause $D(G D S)$.

Results of the Granger Causality tests performed are summarized in Table 8-10. We test up to 5 lags in each of the models.

Table 8: Granger Causality Test results between D(GDP) and D(GDS)

Note: Values in parenthesis denote p-values

$* *$ denote $5 \%$, level of significance

From Table 8, we can conclude that until lag 4, $D(G D P)$ is granger causing $D(G D S)$, while there is no reverse causation. In lag 5 , there is not even bi-directional causalitybetween $D(G D P)$ and $D(G D S)$. When there is economic growth, income of the people increases. So they tend to save more for the future. 
Table 9: Granger causality test results between D(GDS) and D(Debt)

\begin{tabular}{lcc}
\hline Lags & $\boldsymbol{H}_{\mathbf{0}}: \boldsymbol{D}(\boldsymbol{G D S})$ does not Granger Cause $\boldsymbol{D}(\boldsymbol{D E B T})$ & \\
F-statistic & Conclusion \\
\hline 1 & $4.48(0.04)^{* *}$ & $\mathrm{GC}$ \\
2 & $5.71(0.01)^{* *}$ & $\mathrm{GC}$ \\
3 & $5.47(0.01)^{* *}$ & $\mathrm{GC}$ \\
4 & $4.52(0.01)^{* *}$ & $\mathrm{GC}$ \\
5 & $4.61(0.01)^{* *}$ & $\mathrm{GC}$ \\
& $H_{0}: D(D E B T)$ does not Granger Cause $D(G D S)$ & \\
Lags & F-statistic & Conclusion \\
1 & $4.32(0.05)^{* *}$ & $\mathrm{GC}$ \\
2 & $0.97(0.40)$ & Does not GC \\
3 & $7.91(0.00)^{* *}$ & $\mathrm{GC}$ \\
4 & $5.85(0.01)^{* *}$ & $\mathrm{GC}$ \\
5 & $9.70(0.04)^{* *}$ & $\mathrm{GC}$ \\
\hline
\end{tabular}

Note: Values in parenthesis denote p-values** denote $5 \%$, level of significance

From Table 9, we can conclude there is bi-directional causality between debt and savings. $D(G D S)$ granger causes $D(D E B T)$ up to lag 5 , while $D(D E B T)$ granger causes $D(G D S)$ up to 5 lags except for lag 2.

Table 10: Granger Causality Test results between D(GDP) and D(Debt)

\begin{tabular}{ccc}
\hline Lags & $\boldsymbol{H}_{\mathbf{0}}: \boldsymbol{D}(\boldsymbol{G D P})$ does not Granger Cause $\boldsymbol{D}(\boldsymbol{D E B T})$ & \\
F-statistic & Conclusion \\
\hline 1 & $7.21(0.01)^{* *}$ & $\mathrm{GC}$ \\
2 & $4.01(0.03)^{* *}$ & $\mathrm{GC}$ \\
3 & $1.24(0.31)$ & Does not GC \\
4 & $1.29(0.31)$ & Does not GC \\
5 & $2.55(0.07)^{*}$ & $\mathrm{GC}$ \\
& $H_{0}: D(D E B T)$ does not Granger Cause $D(G D P)$ & \\
Lags & F-statistic & Conclusion \\
1 & $1.32(0.26)$ & Does not GC \\
2 & $1.35(0.28)$ & Does not GC \\
3 & $3.44(0.03)^{* *}$ & GC \\
4 & $2.94(0.05)^{* *}$ & GC \\
5 & $2.91(0.04)^{* *}$ & GC \\
\hline
\end{tabular}

Note: Values in parenthesis denote p-values** and $*$ denote $5 \%$, and $10 \%$ level of significance respectively

From the Table 10, we find that up to 2 lags, $D(G D P)$ tends to granger cause $D(D E B T)$, while there is no reverse causation. For lags 3 and $4, D(D E B T)$ is granger causing $D(G D P)$. For lag 5, $\mathrm{D}(D E B T)$ granger causes $D(G D P)$ and $D(G D P)$ also granger causes $D(D e b t)$.

So, we conclude that in the short run, it is GDP that is impacting Debt, while in the long run; we assume a bi-directional causality between GDP and Debt. It follows normal logic too. Normally, when there is recession (period of poor economic growth), debt tends to increase as Government and individuals might resort to increased precautionary and expansionary spending (in form of deficit financing).

\section{SUMMARY AND CONCLUSIONS}

This paper aimed to investigate the relationship between domestic debt and economic growth in the Indian context. While there have been many theoretical discussions of how domestic debt impact economic growth, empirical study on the same provides contradicting results. While some studies support the Ricardian equivalence, others support the traditional view. This study used data on 
Domestic Debt, Net Fiscal Deficit, Exports, Savings, Real Gross Domestic Product, Population and Terms of Trade for the period 1980 - 2014. This study adopted the ARDL Co-Integration and Granger Causality techniques to investigate the relation between the key variables. The study also employed various post estimation tests to validate the fitness and stability of the models after employing the ordinary least square regression on various models.

We find that debt negatively impacts economic growth, thereby supporting the traditional view while savings has a positive impact. The Auto Regressive Distributed Lag (ARDL) technique used to test the robustness suggests existence of co-integration among the variable. However, none of the long run co-efficient is significant. The granger causality test results conclude that in the short run, it is GDP that is impacting Debt, while in the long run; we assume a bi-directional causality between GDP and Debt. There exists bi-directional causality between Debt and Savings, while GDP is impacting Savings with no reverse causation.

Views and opinions expressed in this study are the views and opinions of the authors, Asian Journal of Empirical Researchshall not be responsible or answerable for any loss, damage or liability etc. caused in relation to/arising out of the use of the content.

\section{References}

Abbas, A.,\&Jakob, C. (2007). The role of domestic debt markets in economic growth: An empirical investigation for low-income countries and emerging markets. IMF Working Paper, No.07/127.

Anja, B., Cristina, C. W., \& Philipp, R. (2012). Debt and growth: New evidence for the Euro area. Working Paper Series, European Central Bank.

Barro, R. J. (1974). Are government bonds net wealth?Journal of Political Economy, 82, 1095-1117.

Barro, R. J. (1978a). Comment from an unreconstructed Ricardian.Journal of Monetary Economics, 4, 569-581.

Brahmananda, P. R. (1980). Growthlessinflation by means of stockless money. Himalaya Publishing House, Bombay.

Buchanan, J. M. (1958). Public principles of public debt. Irwin, Homewood, IL.

Cashell, B. W. (2007). The federal government debt: Its size and economic significance. CRS Report for Congress, Congressional Research Service.

Charan, S. (1999). Domestic debt and economic growth in India.Economic and Political Weekly, 34(23), 1445-1453.

Chelliah, R. J. (1991). Growth of Indian public debt-dimensions of the problem and corrective measures. IMF Working Paper, No. 91/72.

Ferguson, J.M.(ed). (1964). Public debt and future generations. University of North Carolina Press, Chapel Hill.

Jakob, C. (2005). Domestic debt markets in Sub-Saharan Africa.IMF Staff Papers, 52(3), 518-538.

Granger, C.W. J. (1969). Investigating causal relations by econometric models and cross- spectral methods.Econometrica, 37, 424-438.

Granger, C.W. J. (1986). Developments in the study of Cointegrated economic variables.Oxford Bulletin of Economics and Statistics, 48(3),213-228.

Hendry, D. F. (1996). Dynamic econometrics. Oxford University Press, Oxford.

Karazijienè, Ž., \&Sabonienè, A. (2009). The structure of the NATIONAL debt and state's borrowing influence for the Lithuanian economy.Economics and Management, 14, 271279.

Kemal, A. R. (2001). Debt accumulation and its implications for growth and poverty.The Pakistan Development Review, 40(4), 263-281.

Kristine, F., Lycia, L., \&Ugo, P. (2011). The determinants of the composition of public debt in developing and emerging market countries.Review of Development Finance, 1(3),207-222.

Meltzer, L. A. (1951). Wealth, saving, and the rate of interest. Journal of Political Economy, 59, 93116. 
Minhas, B. S. (1987). The planning process and the annual budgets: some reflections on recent Indian experience.Indian Economic Review, 22, 115-149.

Mill, J. S. (1845). Principles of political economy. Fairfield, New Jersey.

Modigliani, F. (1961). Long run implications of alternative fiscal policies and the burden of national debt.Economic Journal,71,730-755.

Mustafa, I.,\&Gulcin, O. (2012). Public debt and financial development: A theoretical exploration.Economic Letters, 3, 115-119.

Patinkin, D. (1965). Money, interest, and prices. Harper\& Row; New York, pp. 230-235.

Pesaran, M.H., Shin, Y., \& Smith, R. J. (2001). Bounds testing approaches to the analysis of level relationships.Journal of Applied Econometrics, 16, 289-326.

Rao, V.K.R. V. (1953). Deficit financing, capital formation and price behaviour in an underdeveloped economy.Eastern Economist Pamphlets, 20, 3-10.

Ricardo,D. (1951). On the principles of political economy and taxation.In Saraffa, P.(Ed).

RBI (1985). Report of the committee to review the working of the monetary system.Reserve Bank of India, Bombay.

Smith, A. (1976), In Canaan, E.(Ed): The wealth of nations. Random House, New York. 


\section{APPENDIX I}

i. CUSUM Stability Test Results
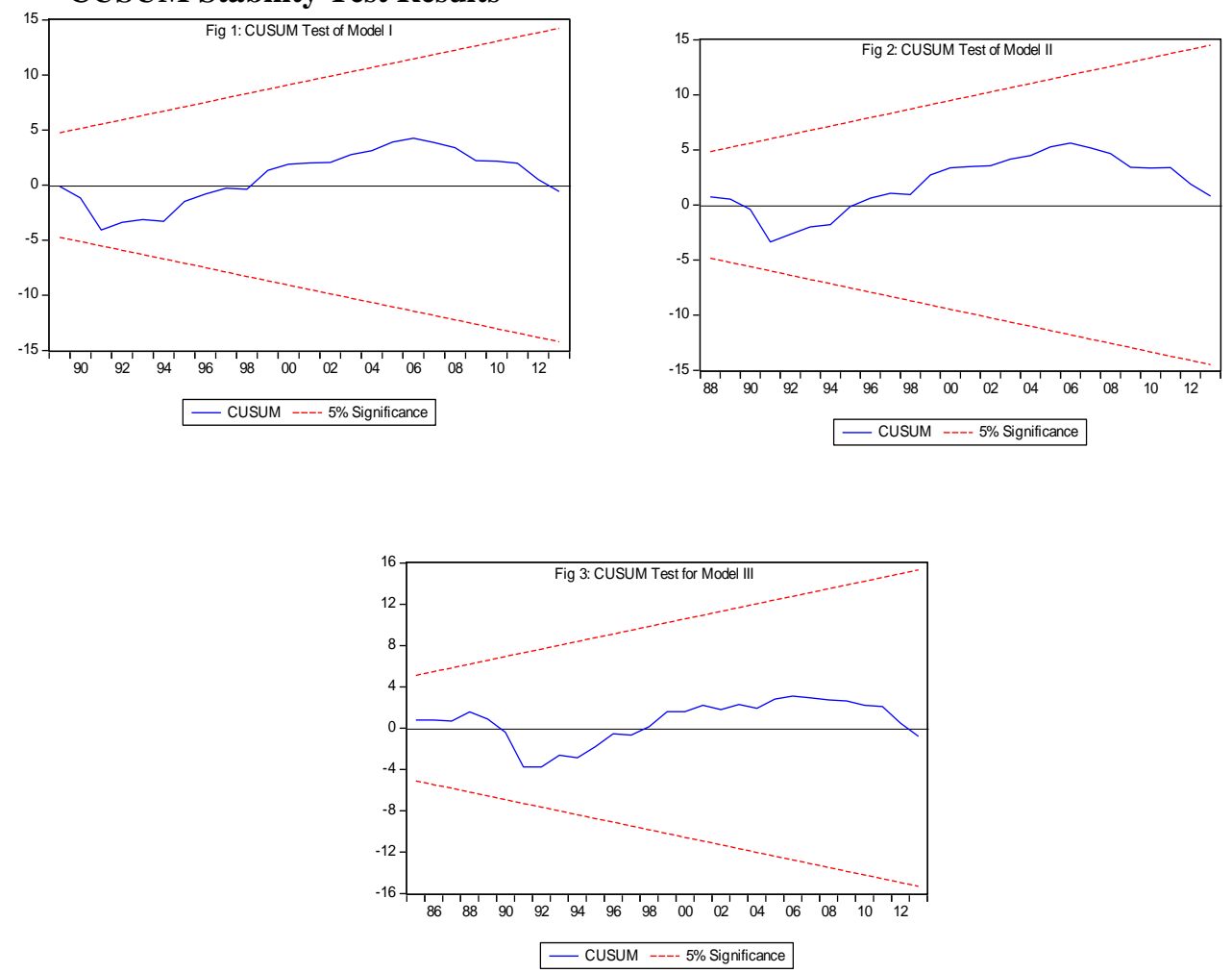

\section{ii. CUSUM of Squares Stability Test Results}
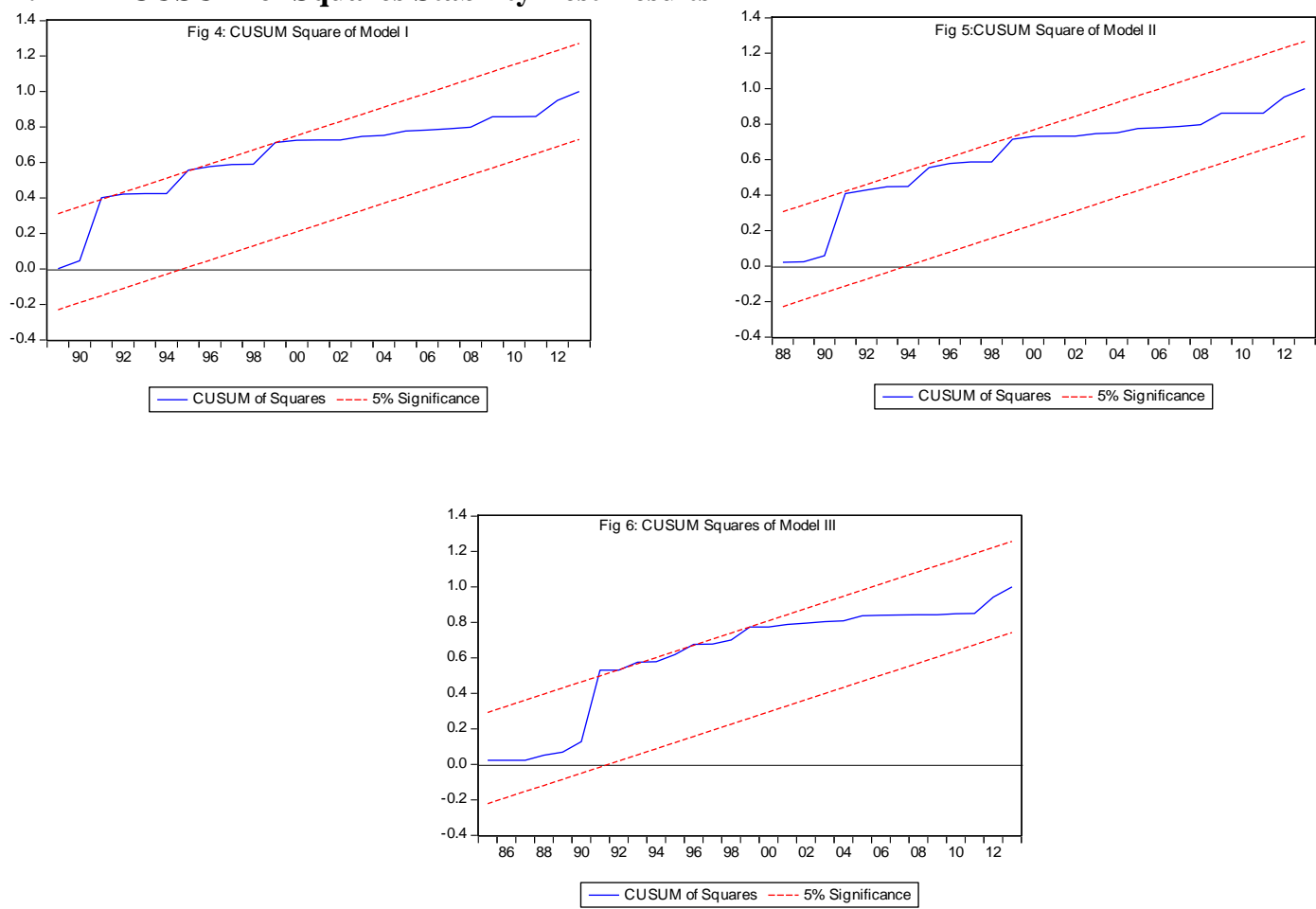